\title{
PENINGKATAN HASIL BELAJAR MATEMATIKA MELALUI TEORI APOS PADA SISWA KELAS VIIC MTS HUSNUL KHATIMAH
}

\author{
Fatimah $^{1^{*}}$, Yolinika Tampani², Muh Izabi Alis Pindi ${ }^{3}$ \\ 1,2Universitas Al Asyariah Mandar \\ 3SMK Negeri 1 Polewali \\ *Email: fatimahrayyan1982@gmail.com
}

\begin{abstract}
This research is a classroom action research (CAR) which aims to find out the improvement of mathematics learning outcomes through the theory of apos learning in class VIIc students of MTs Husnul Khatimah. The subjects of this study were the students of class VIIc MTs husnul khatimah, totaling 21 students. This research was conducted in two cycles. The work procedure of each research cycle takes four stages, namely (1) planning, (2) implementing actions, (3) observation, (4) reflection. Data collection is done by providing test results of learning and observation trough observation sheets. Data collected were analyzed by quantitative and qualitative analysis. The results of the study concluded that mathematics learning outcomes have increased trough the theory of apos learning class VIIc students MTs Husnul Khatimah. This is shown by : (1) the increase in the average score of students mathematics learning outcomes is 76,35 in cycle 1 to 86,06 in cycle II; (2) the increase in the percentage of students who complete learning is $71,42 \%$ in cycle 1 to $95,23 \%$ in cycle $2:$ and (3) the increase in student activities that are in accordance with learning from cycle 1 to cycle 2 while student activities that are not in line with learning are decreasing.
\end{abstract}

Keywords: mathematics learning outcomes, improvement, APOS theory

\section{PENDAHULUAN}

Pendidikan merupakan media utama dalam mencerdaskan bangsa. Dengan pendidikan kita dapat menciptakan generasi-generasi muda yang intelektual, yang dapat menjadikan Bangsa Indonesia lebih berkembang dalam segala bidang. Dalam menciptakan benerasi-generasi yang berintelektual tidak hanya pemberian materi pelajaran saja, ada faktor-faktor yang mempengaruhi pemahaman siswa (generasi muda) terhadap mata pelajaran yang disampaikan. Misalnya, kemampuan siswa dalam memahami materi, kemampuan guru dalam menyajikan materi, suasana kelas, sarana dan prasarana prndukung, bobot materi yang 
disampaikan, metode pembelajaran dan lain sebagainya (Bahri, 2016).

Matematika merupakan suatu bahan kajian yang memiliki objek abstrak dan dibangun melalui proses penalaran dedukatif, yaitu kebenaran suatu konsep diperoleh sebagai akibat logis dari kebenaran sebelumnya sudah diterima, sehingga keterkaitan antar konsep dalam matematika bersifat sangat kuat dan jelas. Dalam pembelajaran matematika agar mudah dipahami oleh siswa, proses penalaran induksi dapat dilakukan pada awal pembelajaran dan kemudian dilanjutkan dengan proses penalaran dedukatif untuk menguatkan pemahaman yang sudah dimiliki oleh siswa didik (Karso, dkk. 2012).

Matematika memiliki peranan sebagai bahasa simbolik yang memungkinkan terwujudnya komunikasi yang cermat dan tepat. Namun kenyataannya berbeda matematika seringkali dianggap sebagai mata pelajaran yang sulit bagi siswa (Anni, 2014:10).

Berbagai Upaya telah dilakukan oleh pemerintah dalam memperbaiki mutu pendidikan khususnya belajar matematika siswa yang masih rendah, siantaranya penyempurnaan kurikulum, pengadaan buku paket, peningkatan pengetahuan dan wawasan guru melalui penataran, baik secara regional maupun nasional. Selain itu, telah dilakukan berbagai penelitian terhadap faktor-faktor yang diduga mempengaruhi hasil belajar matematika masih jauh dari yang diharapkan (Samad, 2017)

Berdasarkan hasil observasi awal di MTs Husnul Khatimah dengan guru mata pelajaran matematika diperoleh data bahwa, hasil belajar peserta didik kelas VIIc yang berjumlah 21 orang masih relatif rendah. Hal ini nampak dari masih banyaknya peserta didik yang memeroleh nilai hasil belajar matematika yang belum mencapai nilai KKM (KKM = 70). Nilai yang diperoleh siswa berkisar pada interval 65 - 75. Dengan jumlah siswa yang tuntas 6 orang $(33,33 \%)$ dan yang belum tuntas 14 orang $(66,67, \%)$. Olehnya itu dalam upaya meningkatkan hasil belajar matematika peserta didik kelas VIIc di MTs Khusnul Khotimah, maka dalam penelitian ini akan diterapkan teori APOS dalam pembelajaran. Beberapa penelitian terdahulu mengungkapkan bahwa teori apos dapat meingkatkan hasil belajar matematika siswa ataupun mahasiswa. (Anwar. 2016) dalam penelitiannya menyimpulkan bahwa teori APOS dapat meningkatkan keaktifan dan hasil belajar mahasiswa dari siklus I ke siklus II.

Teori APOS merupakan teori kontruktivis yang dikembangkan oleh Dubinsky. Teori ini mengasumsikan bahwa pengetahuan matematika yang dimiliki oleh seseorang merupakan hasil interaksi dengan orang lain dan hasil konstruksi-konstruksi mental orang tersebut dalam memahami ide-ide matematika (Arnawa, 2009). Tahapan teori APOS diantaranya aksi (action), proses (process), obyek (object), dan skema (schema). Manakala seseorang berusaha memahami suatu ide matematik maka prosesnya akan dimulai dari suatu Aksi, Proses, Objek dan berakhir pada Skema (Hanifa, 2016) 
Dubinsky and Mcdonald (Marsitin, 2017), menyatakan bahwa Action, yaitu suatu transformasi objek-objek mental untuk memperoleh obyek mental lainnya. Process, yaitu ketika suatu aksi diulangi dan terjadi refleksi atas aksi yang dilakukan. Object, yaitu objek kajian matematika yang dikaji. Schema, yaitu koleksi aksi, proses, objek, dan skema yang saling terhubung. Hal ini hampir sama dengan yang dikemukakan oleh (Ningsih \& Rohana, 2018) yang menyatakan bahwa Individu yang sudah mengkonstruksi konsep proses dapat menguraikan atau bahkan membalikkan langkah-langkah dari transformasi tanpa benar-benar melakukannya.

(Kusaeri, 2015) menjelaskan bahwa Konsepsi aksi adalah suatu transformasi objek-objek matematika berdasarkan pada sebuah algoritma tertentu untuk memperoleh objek matematika lainnya; Konsepsi proses merupakan transformasi internal tentang suatu objek; konsepsi objek merupakan kajian matematika yang dipelajari; sedangkan konsepsi skema merupakan kumpulan dari konsepsi aksi, proses, dan objek serta skema itu sendiri yang telah terkonstruk sebelumnya, sehingga terbentuk struktur matematika yang diperlukan dalam pemecahan masalah matematika. Skema adalah suatu totalitas pemahaman individu terhadap suatu konsep yang sejenis (Hanifa, 2016)

Dubinsky (Febriani, 2019) menjelaskan bahwa teori APOS dapat bermanfaat dalam mengoptimalkan tingkat pemahaman siswa, sementara (Herdian, dkk.2019) mengemukakan bahwa teori ini dapat digunakan untuk membandingkan kemampuan individu dalam mengkonstruksi mental yang telah terbentuk untuk suatu konsep matematika.

Indikator masing-masing tahapan teori APOS berdasarkan beberapa teori terdahulu dijelaskan pada gambar 1.

\begin{tabular}{|c|c|}
\hline $\begin{array}{c}\text { Aksi } \\
\text { (Action) }\end{array}$ & $\begin{array}{l}\text { - siswa memfokuskan proses mentalnya pada upaya untuk } \\
\text { memahami suatu konsep yang diberikan; }\end{array}$ \\
\hline $\begin{array}{l}\text { Proses } \\
\text { (Process) }\end{array}$ & $\begin{array}{l}\text { - Berpikir siswa terbatas pada ide matematik yang dihadapi serta } \\
\text { ditandai dengan munculnya kemampuan untuk melakukan } \\
\text { refleksi terhadap ide matematika tersebut; }\end{array}$ \\
\hline $\begin{array}{c}\text { Objek } \\
\text { (object) }\end{array}$ & $\begin{array}{l}\text { - siswa mampu memperlakukan idea atau konsep sebagai sebuah } \\
\text { objek kognitif yang mencakup kemampuan untuk melakukan } \\
\text { aksi atas objek tersebut, } \\
\text { - memberikan alasan atau penjelasan tentang sifat-sifat objek } \\
\text { - mampu melakukan penguraian kembali suatu ojek menjadi } \\
\text { proses sebagai mana asalnya pada saat sifat-sifat dari objek yang } \\
\text { dimaksud akan digunakan; } \\
\text { - mampu menjelaskan sifat-sifat dari konsep matematika, }\end{array}$ \\
\hline $\begin{array}{c}\text { Skema } \\
\text { (Schema) }\end{array}$ & $\begin{array}{l}\text { - Siswa mampu untuk mengkonstruk contoh-contoh suatu konsep } \\
\text { matematika sesuai dengan sifat-sifat yang dimiliki konsep } \\
\text { tersebut, atau sesuai dengan persyaratan yang telah ditentukan }\end{array}$ \\
\hline
\end{tabular}

Gambar 1. Indikator teori APOS 


\section{METODE PENELITIAN}

Penelitian yang dilakukan adalah Penelitian Tindakan Kelas (Classroom Action Research). (Arikunto, 2010) menjelaskan bahwa penelitian tindakan kelas (PTK) adalah penelitian yang dilakukan dengan suatu pencermatan terhadap kegiatan belajar berupa sebuah tindakan yang sengaja dimunculkan dan terjadi dalam sebuah kelas secara bersama.

Penelitian ini dilakukan secara kolaboratif antara kepala sekolah, guru kelas dan peneliti, kegiatan penelitian meliputi: perencanaan (planning), pelaksanaan (action), pengumpulan data (observing) dan menganalisis data/informasi untuk memutuskan sejauh mana kelebihan atau kelemahan tindakan tersebut (reflecting).

Lokasi penelitian bertempat di MTs Husnul Khatimah Kecamatan Polewali Kabupaten Polewali Mandar dengan subjek penelitian adalah siswa kelas VIIc dengan jumlah peserta didik 21 orang yang terdiri dari 10 orang laki-laki dan llorang perempuan.

Pelaksanaan tindakan yaitu tahap mengimplementasikan pelaksanaan pembelajaran menggunakan teori APOS pada Materi aritmatika sosial yang telah disusun secara kolaboratif dengan guru mata pelajaran Matematika. Pada penelitian ini terlaksana sebanyak dua siklus, dengan masing-masing tahapan disajikan pada gambar 2 .

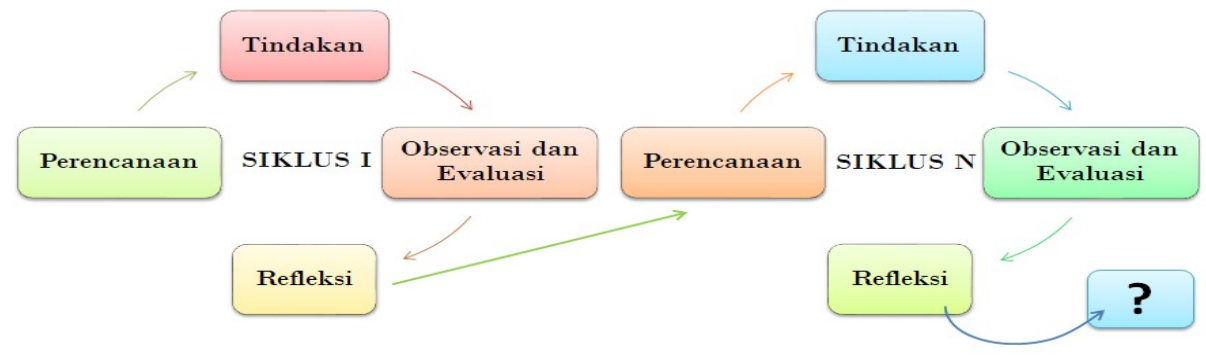

Gambar 2. Tahapan PTK

Tahapan pelaksanaan PTK dimana tahap tindakan berdasarkan pada Teori Apos yang diadaptasi dari suryadi (Hanifa 2016) dijelaskan pada tabel 1.

Tabel 1. Tahapan Kegiatan PTK berdasarkan Teori APOS

\begin{tabular}{|l|l|}
\hline Tahapan PTK & \multicolumn{1}{|c|}{ Tahapan Kegiatan/ Pembalejaran } \\
\hline Perencanaan & $\begin{array}{l}\text { Analisis silabus, pembuatan administrasi pembelajaran (RPP, } \\
\text { LKS) dan Instrumen penelitian (Pedoman Observasi dan Tes } \\
\text { Siklus) }\end{array}$ \\
\hline
\end{tabular}




\begin{tabular}{|c|c|}
\hline \multirow[t]{4}{*}{ Tidakan } & $\begin{array}{l}\text { 1. Awal pembelajaran, guru memotivasi siswa melakukan } \\
\text { kegiatan manganalisis masalah-masalah yang berkaitan } \\
\text { dengan konsep aritmetika sosial menggunakan konsep- } \\
\text { konsep yang telah dimiliki siswa sehingga pikirannya akan } \\
\text { fokus pada konsep matematika yang dipelajarinya. Hal ini } \\
\text { akan memicu siswa untuk memiliki aksi. }\end{array}$ \\
\hline & $\begin{array}{l}\text { 2. Saat proses pembelajaran berlangsung, guru bertindak } \\
\text { sebagai fasilitator dan memberikan petunjuk secara tidak } \\
\text { langsung sehingga siswa termotivasi untuk melakukan } \\
\text { pembahasan konsep matematika lebih mendalam dan lebih } \\
\text { umum. Hal ini akan memicu siswa untuk memiliki proses } \\
\text { konsep matematika. }\end{array}$ \\
\hline & $\begin{array}{l}\text { 3. Jika diperlukan guru harus melakukan intervensi secara } \\
\text { tidak langsung sehingga siswa dapat menemukan atau } \\
\text { mensintesis sifat-sifat konsep matematika. Hal ini akan } \\
\text { memicu siswa untuk memiliki objek konsep matematika }\end{array}$ \\
\hline & $\begin{array}{l}\text { 4. Di akhir pembelajaran, dosen harus memberikan tugas } \\
\text { penerapan konsep dan tugas mengkonstruksi contoh- } \\
\text { contoh konsep matematika yang memenuhi syarat-syarat } \\
\text { tertentu, memicu siswa untuk memiliki skema konsep } \\
\text { matematika }\end{array}$ \\
\hline $\begin{array}{l}\text { Observasi dan } \\
\text { Evaluasi }\end{array}$ & $\begin{array}{l}\text { Melakukan pengamatan terhadap aktivitas guru dan siswa } \\
\text { saat pembelajaran saat diterapkannya teori apos, serta } \\
\text { melakukan evaluasi terhadap pemahaman siswa atas materi } \\
\text { yang telah dibahas melalui pembelrian THB pada setiap } \\
\text { akhir siklus }\end{array}$ \\
\hline Refleksi & $\begin{array}{l}\text { Melakukan refleksi atas kelemahan-kelemahan yang mungkin } \\
\text { terjadi dan melakukan upaya perbaikan pada siklus } \\
\text { berikutnya, sampai pada penarikan kesimpulan berdasarkan } \\
\text { indikator capaian penelitian. }\end{array}$ \\
\hline
\end{tabular}

Data hasil penelitian dikumpulkan menggunakan instrumen Tes hasil belajar yang diberikan pada setiap akhir siklus dan pedoman Observasi yang dilaksanakan dalam setiap pembelajaran dengan menerapkan teori APOS pada peserta didik dan guru. Data yang terkumpul dianalisis dengan menggunakana analisis statistik deskriptif baik secara kuantitatif maupun secara kualitatif.

Indikator keberhasilan pelaksanaan penelitian dengan menerapkan teori APOS dalam pembelajaran matematika adalah: 
1. Hasil Belajar

Terjadi peningkatan skor rata - rata hasil belajar matematika peserta didik kelas VIIc MTs Husnul khatimah dari siklus I ke siklus II dan ketuntasan hasil belajar siswa mencapai ketuntasan klasikal yaitu $85 \%$.

Tabel 2.Kategori Ketuntasan Hasil Belajar Matematika MTs Khusnul Khotimah Sumber: Guru Matematika MTs Husnul Khatimah

\begin{tabular}{|c|c|}
\hline Nilai & Kategori \\
\hline $70 \leq$ nilai $\leq 100$ & Tuntas \\
\hline $0 \leq$ Nilai $<70$ & Tidak Tuntas \\
\hline
\end{tabular}

2. Aktifitas Peserta Didik dalam Pembelajaran:

Observasi terhadap aktivitas peserta didik dalam pembelajaran dilakukan oleh observer dengan menggunakan lembar observasi. Indikator ini dikatakan tercapai apabila rata-rata persentase peserta didik melakukan aktivitas yang sesuai dengan pembelajaran saat diterapkannya teori APOS dalam pembelajaran matematika berada pada kategori sangat aktif.

Tabel 3. Kategori tingkat keaktifan matematika peserta didik

Sumber: Arikunto (Alimuddin, 2107)

\begin{tabular}{|c|c|}
\hline $\begin{array}{c}\text { Rentang Persentase Hasil Keaktifan } \\
\text { Belajar Matematika }(\%)\end{array}$ & Kategori \\
\hline $\mathrm{P}>80$ & Sangat Aktif \\
\hline $60<\mathrm{P} \leq 80$ & Aktif \\
\hline $40<\mathrm{P} \leq 60$ & Cukup Aktif \\
\hline $20<\mathrm{P} \leq 40$ & Kurang Aktif \\
\hline $\mathrm{P}<20$ & Tidak Aktif \\
\hline
\end{tabular}

\section{HASIL DAN PEMBAHASAN}

Sajian data Hasil Penelitian pada Siklus I dan siklus II meliputi data hasil observasi dan hasil belajar matematika peserta didik melalui penerapan Teori APOS dalam pembelajaran matemtika.

1. Hasil observasi Penelitian Siklus I dan II

Tabel 4. Hasil observasi aktivitas siswa siklus I dan II

(Sumber: hasil Analisis Data, 2019)

\begin{tabular}{|c|c|c|c|c|c|c|c|c|c|}
\hline \multirow{2}{*}{ No } & $\begin{array}{c}\text { Komponen yang } \\
\text { diamati }\end{array}$ & \multicolumn{3}{|c|}{ Siklus I Pertemuan Ke- } & \multicolumn{4}{|c|}{$\begin{array}{c}\text { Siklus II Pertemuan } \\
\text { Ke- }\end{array}$} \\
\cline { 2 - 9 } & I & II & III & \% & I & II & III & $\%$ \\
\hline 1 & $\begin{array}{l}\text { Siswa memperhatikan } \\
\text { guru saat penyampaian } \\
\text { materi ajar aritmatika } \\
\text { sosial }\end{array}$ & 18 & 20 & 21 & 93,64 & 19 & 20 & 21 & 95,23 \\
\hline
\end{tabular}




\begin{tabular}{|c|l|c|c|c|c|c|c|c|c|}
\hline \multirow{2}{*}{ No } & \multicolumn{1}{|c|}{$\begin{array}{c}\text { Komponen yang } \\
\text { diamati }\end{array}$} & \multicolumn{3}{|c|}{ Siklus I Pertemuan Ke- } & \multicolumn{3}{c|}{$\begin{array}{c}\text { Siklus II Pertemuan } \\
\text { Ke- }\end{array}$} \\
\cline { 3 - 9 } & & I & II & III & \% & I & II & III & $\%$ \\
\hline 2 & $\begin{array}{l}\text { Siswa membaca materi } \\
\text { yang akan di pelajari } \\
\text { dan membuat peta } \\
\text { konsep }\end{array}$ & 10 & 10 & 15 & 55,48 & 15 & 20 & 21 & 88,88 \\
\hline 3 & $\begin{array}{l}\text { Siswa menyelesaikan } \\
\text { permasalahan dalam } \\
\text { LKS (tanpa } \\
\text { menggunakan } \\
\text { komputer) secara } \\
\text { berkelompok (diskusi } \\
\text { Kelompok) }\end{array}$ & 5 & 8 & 10 & 36,05 & 15 & 18 & 20 & 84,12 \\
\hline 4 & $\begin{array}{l}\text { Siswa yang bermaksud } \\
\text { mempresentasikan } \\
\text { hasil diskusi yang telah } \\
\text { diselesaikan (diskusi } \\
\text { Kelas) }\end{array}$ & 18 & 20 & 20 & 82,53 & 18 & 20 & 20 & 92,05 \\
\hline 5 & $\begin{array}{l}\text { Siswa yang berhasil } \\
\text { menyelesaikan soal } \\
\text { latihan yang diberikan } \\
\text { (Latihan) }\end{array}$ & 20 & 20 & 21 & 93,64 & 20 & 21 & 21 & 96,82 \\
\hline 6 & $\begin{array}{l}\text { Siswa yang tergolong } \\
\text { sangat aktif dalam } \\
\text { proses }\end{array}$ & 6 & 8 & 10 & 38,09 & 16 & 17 & 18 & 80,95 \\
\hline 7 & $\begin{array}{l}\text { Siwa yang dapat } \\
\text { menyimpulkan materi } \\
\text { pembelajaran }\end{array}$ & 10 & 12 & 18 & 63,49 & 19 & 20 & 21 & 95,23 \\
\hline
\end{tabular}

Pada siklus I, Siswa yang memperhatikan guru saat menjelaskan materi ajar pada pertemuan 1 sebanyak 18 orang, 3 orang dari total peserta didik yang hadir sering keluar masuk kelas tanpa seijin guru. Pada pertemuan kedua terdapat 1 orang peserta didik tidak hadir (tanpa keterangan). Pada pertemuan ketiga seluruh siswa sudah memperhatikan pembelajaran yang sedang berlangsung. Rata-rata persentase peserta didik yang hadir dan memerhatikan penjelasan guru pada pada saat proses pembelajaran pada siklus I adalah 93,64\%. Pada siklus II, jumlah siswa yang memerhatikan penjelasan guru sesuai dengan jumlah siswa yang hadir saat pembelajaran matematika berlangsung, rata-rata persentase pada amatan ini di siklus II adalah 95,23\%. 
Siswa yang membaca materi yang akan dipelajari dan membuat peta konsep pada pertemuan pertama dan kedua masih $47,62 \%$ dan pada pertemun ketiga meningkat menjadi $71,43 \%$ rata-rata persentase siswa yang mampu membuat peta pikiran selama siklus I sebesar 55,48\% dan meningkat menjadi $88,88 \%$ pada siklus II. Rata-rata Persentase siswa yang menjawab pertanyaan guru pada siklus I baru mencapai $84,12 \%$,dan mengalami peningkatan pada siklus II menjadi 84,12\%. Pada siklus I rata-rata persentase Siswa menyelesaiakan soal yang diberikan oleh guru sebesar 93,64, hal ini tidak jauh berbeda dengan rata-rata persentase pada siklus II yaitu $96,82$.

Secara umum dari siklus I ke siklus II terjadi peningkatan aktivitas belajar siswa yang sesuai dengan pembelajaran dengan menggunakan teori APOS. Pada siklus I rata-rata presentase aktivitas siswa sebesar $66,13 \%$ berada pada ketegori aktif (belum mencapai indikator aktifitas siswa pada penelitian, dan mengalami peningkatan pada siklus II menjadi 90,45 \% (kategori sangat aktif) dan telah mencapai indikator penelitian.

\section{Data Hasil Belajar Peserta Didik pada Siklus I dan Siklus II}

Pelaksanaan tes pada Siklus I dilakukan setelah dilaksanakan pembelajaran menggunakan terori APOS selama 3 kali pertemuan, begitupun pada siklus II. Deskripsi hasil belajar yang diperoleh peserta didik disajikan dalam tabel 5 .

Tabel 5. Statistik hasil belajar matematika peserta didik Kelas VII C MTs Khusnul Khatimah (Sumber Data: hasil analisis data, 2019)

\begin{tabular}{|c|c|c|}
\hline Deskripsi & Statistik Siklus I & Statistik Siklus II \\
\hline Subjek & 21 & 21 \\
\hline Skor Ideal & 100 & 100 \\
\hline Skor Tertinggi & 89,28 & 96,29 \\
\hline Skor Terendah & 60,71 & 66,66 \\
\hline Rentang Skor & 28,57 & 29,63 \\
\hline Skor rata-rata & 76,35 & 86,06 \\
\hline Standar Deviasi & 8,48 & 8,191 \\
\hline
\end{tabular}

Tabel 5 mendeskripsikan bahwa skor rata-rata hasil belajar matematika siswa setelah diterapkan teori APOS dalam pembelajaran matematika materi aritmetika sosial mengalami peningkatan dari siklus I ke siklusi II. pada siklus I diperoleh nilai rata-rata 76,35 dan meningkat menjadi 86,06 pada siklus II. Hal ini sejalan dengan penelitian yang dilakukan oleh (Anwar \& Abdillah. 2016) yang menyimpulkan bahwa terjadi peningkatan rata-rata hasil belajar mahasiswa dari siklus I $(66,11)$ ke Siklus II $(75,83)$.

Deskripsi ketuntasan hasil belajar matematika pesrta didik Kelas VII C MTs Khusnul Khatimah diguankan untuk mengetahui sejauh mana indikator 
ketuntasan belajar secara klasikal telah dicapai peserta didik dalam pembelajaran matematika melalui penerapan teori APOS pada siklus I dan siklus II. Deskripsi ketuntasn hasil belajar matematika peserta didik berdasarkan nilai KKM disajikan pada tabel 5 .

Tabel 6. Distribusi frekuensi ketuntasan belajar matematika siswa kelas VIIc MTs Khusnul Khatimah

(Sumber Data: hasil analisis data, 2019)

\begin{tabular}{|c|c|c|c|c|c|}
\hline \multirow{2}{*}{ Interval Skor } & \multirow{2}{*}{ Kategori } & \multicolumn{2}{c|}{ Siklus I } & \multicolumn{2}{c|}{ Siklus II } \\
\cline { 3 - 6 } & & Frekuensi & $(\%)$ & Frekuensi & $(\%)$ \\
\hline $70 \leq \mathrm{S} \leq 100$ & Tuntas & 14 & 66,67 & 20 & 95,23 \\
$0 \leq \mathrm{S}<70$ & Tidak tuntas & 7 & 33,33 & 1 & 4,76 \\
\hline \multicolumn{2}{|c|}{ Jumlah } & 21 & 100 & 21 & 100 \\
\hline
\end{tabular}

Tabel 6, menggambarkan bahwa pada siklus I baru $66,67 \%$ peserta didik yang tuntas secara klasikal, sementara kriteria ketuntasan yang ditetapkan dalam penelitian yaitu $80 \%$. Sehingga dapat dikatakan bahwa hasil belajar matematika peserta didik MTs Khusnul Khotimah setelah pembelajaran melalui teori APOS pada siklus I belum tuntas secara klasikal. Pada silkus II ketuntasan klasikal telah tercapai dengan persentase perolehan ketuntasan sebesar 95,23\%. Ini berarti bahwa hasil belajar peserta didik secara klasikal telah terpenuhi berdasarkan indikator penelitian. Hal ini didukung oleh penelitian yang dilakukan oleh (Marsitin 2017) yang menyimpulkan bahwa kemampuan akademik mahasiswa meningkat dari siklus I ke siklus II. Simpulan ini diperoleh berdasarkan peningkatan kemampuan koneksi matematis dan kemampuan berpikir kreatif mahasiswa dari siklus I ke siklus II, yaitu 55,31\% menjadi $80,56 \%$ untuk kemampuan koneksi matematis dan 52,14\% menjadi $81,27 \%$ untuk kemampuan berpikir kreatif.

\section{SIMPULAN}

Berdasarkan hasil analisis data dan pembahasan, maka simpulan penelitian ini adalah terjadi peningkatan hasil belajar matematika peserta didik kelas VIIc MTs Khusnul Khotimah dari siklus 1 ke siklus 2 setelah diterapkannya teori APOS dalam pembelajaran matematika materi aritmatika sosial. Selain itu juga terjadi peningkatak aktivitas siswa yang positif selama pempelajaran berlangsung.

\section{SARAN DAN REKOMENDASI}

Teori apos dapatdijadikan salah satu referensi dalam pembelajaran matematika, sehingga guru mampu membedakan kemampuan siswa secara signifikan yang nampaknya memiliki kemampuan matematika yang sama. 


\section{DAFTAR PUSTAKA}

Alimuddin, H. (2017). Pengaruh Keaktifan Belajar Siswa Melalui Penerapan Model Pembelajaran Kooperatif Tipe Team Assisted Individualization (TAI) Terhadap Hasil Belajar Matematika Siswa Kelas Vii Smp Negeri 4 Satap Bungoro. Histogram, 1(1), 61-74.

Anni. (2014). Psikologi Pendidikan. Semarang: Unnes Press.

Anwar, Y.S \& Abdillah, A. (2016). Penerapan Teori Apos (Action, Process, Object, Schema) Untuk Meningkatkan Pemahaman Konsep Program Linier Bagi Mahasiswa Program Studi Pendidikan Matematika Tahun Akademik 2015/2016. Jurnal Paedagoria, Jurnal Kajian Penelitian dan Pengembangan Kependidikan. http://journal.ummat.ac.id/index.php/paedagoria/article/view/30

Arikunto, S. (2010). Penelitian Tindakan Kelas.

Arnawa, I. M. (2010). Mengembangkan kemampuan mahasiswa dalam memvalidasi bukti pada aljabar abstrak melalui pembelajaran berdasarkan teori APOS. Jurnal matematika dan Sains, 14(2), 62-68.

Bahri, Hari Aningrawati. (2016). Peningkatan Hasil Belajar Matematika melalui Pembelajaran Kooperatif Group Investigation Pada Siswa Kelas VII Smp Negeri 15 Bulukumba. Jurnal Pendidikan Pepatudzu. Media Pendidikan dan Sosial Kemasyarakatan. Vol. 1, No. 2

Febriani. (2019). Pengaruh Penerapan Pembelajaran Berbasis Teori APOS (Aksi, Proses, Objek, Skema) Terhadap Hasil Belajar Matematika di SMP Negeri 2 Kota Jambi. (on-line) www.e-campu s.fkip. unja.ac.id/ eskripsi /data / pdf/ jurnal_mhs/.../RRA1c209070.pdf

Hanifa. (2016). Model APOS Inovasi pada Pembelajaran Matematika. Bengkulu: Unit Penerbitan FKIP Universitas Bengkulu

Herdian, F., Widada, W., \& Herawaty, D. (2019). Level Berpikir Siswa dalam Memahami Konsep dan Prinsip Bangun Ruang dengan Pendekatan Pembelajaran Etnomatematika Beradasarkan Teori APOS. Jurnal Pendidikan Matematika Raflesia, 4(2), 111-119.

Karso, dkk. (2012). Pendidikan Matematika 1. Jakarta: Universitas Terbuka.

Kusaeri, K. (2017). Terbentuknya konsepsi matematika pada diri anak dari perspektif teori reifikasi dan APOS. Jurnal Pendidikan Matematika (JPM), 1(2), 101-105.

Marsitin, R. (2017). Koneksi matematis dan berpikir kreatif dalam pembelajaran matematika dengan teori APOS. Al-Khwarizmi: Jurnal Pendidikan Matematika dan Ilmu Pengetahuan Alam, 5(1), 87-100.

Ningsih, Y. L., \& Rohana, R. (2018). Pemahaman Mahasiswa Terhadap Persamaan Diferensial Biasa Berdasarkan Teori APOS. JPPM (Jurnal Penelitian dan Pembelajaran Matematika), 11(1). 
p-ISSN: 2087-3476

e-ISSN: 2541-5700
Pepatuzdu: Media Pendidikan dan Sosial Kemasyarakatan

Vol 17, No. 1 Mei 2021

Samad, Irfawandi. (2017). Peningkatan Hasil Belajar Matematika melalui Pembelajaran Quantum Learning pada Siswa Kelas X SMA Negeri 2 Makassar. Jurnal Pendidikan Pepatudzu. Media Pendidikan dan Sosial Kemasyarakatan. Vol. 13, No. 1 